\title{
The Development of Local Community-Based Creative Tourism at Cicadas Area, Bandung
}

\author{
Wientor Rah Mada \& Budi Wibowo
}

\begin{abstract}
Up to this date, Bandung City is still one of tourist destination cities for both domestic and foreign tourists. And with the nickname as a creative city, the tourism in Bandung City should lead to the creative tourism. The effort made by the Local Government of Bandung City that leads to the creative tourism is by establishing creative villages, and one of those villages in Bandung is Cicadas, the Acoustic Village.

The creative tourism has the potential to be developed in Cicadas, but the situation can be manifested in relation to the presence of the stakeholders. Role of the government is very significant in developing the tourism in Cicadas. Fund is one of obstacles complained by the local community of Cicadas. The lack of attention given by the government has made the local community of Cicadas becomes less enthusiast to produce, even develop their creativity potential owned.
\end{abstract}

The effort to develop creative tourism in Cicadas as the Acoustic Creative Village is to recognize the desire of local community. This must be recognized by the local government of Bandung City or for other party that has the interest in tourism sector, in order to know the weakness or advantages of a tourism product or service that has been held all this time.

It is expected that stakeholders or parties that have the role in the development of Cicadas are able to improve the existing weaknesses according to their expectation, thus Cicadas can become an alternative tourism area in Bandung City in the future, which can bring tourists. Therefore it is expected that it can improve the economy level of the community in Cicadas area.

Based on those responses, a number of results are obtained: 1) community members agree to involve tourists in the tourism activities held by Cicadas Acoustic Village for the self-development, 2) community members agree to provide some learning on local cultural-based activities to tourists, and 3) community members do not agree in enabling the use of local skills.

Keywords—Development, local, based tourism and area.

\section{INTRODUCTION}

\section{A. Research Background}

Looking at the presence of Bandung City as a creative city and still becomes one of popular tourism destinations in Indonesia, then Bandung should start to move forward to the creative tourism.

The local government of Bandung City has encouraged the

Wientor Rah Mada, Bandung Institute Of Tourism Indonesia (wrahmada@stp-bandung.ac.id ).

Budi Wibowo, Bandung Institute Of Tourism Indonesia(buw@stpbandung.ac.id). establishment of creative villages, that also corresponds to the nickname of Bandung, which is the Creative City. In the village, there are cultural activities that contain education values which is able to promote the economic sector in Bandung City.

Quoting the statement of the Mayor of Bandung, Ridwan Kamil, "The effort made by the Local Government of Bandung City by establishing creative villages is one of ways to empower the community in a village with a product. The village itself will be established thematically, for instance, a music village, a statue village, and a bird village". (http://swa.co.id/business-strategy/management/ridwan-kamilbandung-akan-menjadi-kota-kreatif/).

From several creative villages in Bandung City, Cicadas is a village that has music creativity which highly potential to be developed further by copying Saung Angklung Ujo in terms of its development and becomes one of the tourist destinations in Bandung City.

Cicadas is a village where most of the community members is a street musician. These days, thugs in Cicadas are starting to actively create songs, play music and even make a guitar for a handicraft. The flanking walls in Cicadas start to have colorful colors with their creative murals. Moreover, there are some creativities owned by them such as drawing, music from waste products (pans, water gallon, bucket, and others), Sundanese dance, pencak silat (martial art) and also lengser (an art performance in a Sundanese wedding ceremony). Futhermore, there is a home industry such as shoemakers, leather bag makers, handicrafts where materials from waste products.

Cicadas has the potential to be developed where it has diversed arts/culture by using the creative tourism concept, so tourists that come to this Cicadas Acoustic Creative Village can participate in several local cultural events, arts or local community activities. But according to the coordinator of Cicadas Acoustic Creative Village, the local community still do not understand further on tourism, but they have a great hope that their village can become a tourist village.

Cicadas has the potential to be developed where it has diversed arts/culture by using the creative tourism concept, so tourists that come to this Cicadas Acoustic Creative Village can participate in several local cultural events, arts or local community activities. But according to the coordinator of Cicadas Acoustic Creative Village, the local community still do not understand further on tourism, but they have a great 
hope that their village can become a tourist village.

Hermantoro (2011:99-107) explains that creative tourism is how to make a recreational tourism be a creative tourism, by prioritizing the role and development of local community, not just become creative people, but capable to be a creativepeneur, being a creative community that also has a deep soul of entrepreneurship. With those results, we make them as our basis of research and we give this research a title:

"The Development of Local Community-Based Creative Tourism at Cicadas Area, Bandung".

\section{B. Formulation of Problem}

Based on the above background that we explained earlier, the identificatoin of problem occurs in the development of Cicadas Creative Village is not all community members involve in the creative activities, whil the entire communities has the potential and can be involved in tourism activities by developing the creative tourism activities in Cicadas Creative Village.

\section{Identification of Problem}

Based on the above background, thus the following research questions arise:

1) What is the response of the local community of Cicadas acoustic creative village, Bandung towards the involvement of tourism in the self-development of tourists in tourism activities at Cicadas Acoustic Creative Village?

2) What is the response of the local community of Cicadas Acoustic Creative Village, Bandung towards the learning on local cultural-based activities in the tourism activities in Cicadas Acoustic Creative Village?

3) What is the response of the local community of Cicadas Acoustic Creative Village, Bandung towards the enabling the use of local skills in the tourism activities in Cicadas Acoustic Creative Village?

\section{II.LITERATURE REVIEW}

\section{A. Urban Tourism}

Klingner (2006: 1) define the urban tourism as a set of tourist resources or activities located in towns and cities and offered to visitors from elsewhere. As a world tourism phenomenon, urban is viewed as a complex process related to the culture, lifestyle, and a set of different demands towards holiday and traveling.

The urban tourism concept grows along with the development of urban tourism across the globe. The urban tourism concept that is currently growing in the world has five concepts, at least, i.e. tourist-historic city, cultural city, fantasy city, creative city, and urban eco-tourism.

The creative village is one of environmentally sound-urban tourist destinations. Besides involving local communities with creative tourism activities, a creative village also invites tourists to be aware of how to love the environment further.

In a journal, Safira (2012) explains that a creative village has to have new aspects of a creative product generated. Moreover, that village must bring out an interaction aspect between individu and its environment or culture, and receive a recognition or reward from the community in a certain time.

From the above explanation, it can be summarized that a creative village is a place where the community has the economic values creativity. Creativity is the main capital in facing global challenges. By bringing out a diverse and meaningful interaction without changing the environmental condition and continues to uphold the cultural value owned, it is already become an effort made in the urban development.

\section{B. Creative Tourism}

In the beginning, the creative tourism itself is introduced by Richard and Raymond as "...tourism experience which allows tourist to develop their creative potential..." The above definition explains that there is a tourist involvement as a part of creativity process. If that is related to Cicadas Acoustic Creative Village in Bandung City, then such tourism activities will make tourists to gain education, emotional, and social values towards the life of local communities, which therefore, they will feel that they are a part of the local community themselves. Hermantoro (2011:115).

In an informal context, according to Raymond (2000), the creative tourism that is explained by Priyatmono (2011:20-21) is an experience in tourism that gives the opportunity to tourists to develop its creative potential. Creative tourisms are such as:

1) Not rigid and flexible, such as openness/acceptance of the community to tourists, creative tourism activities are involving tourists.

2) The theme is related to local culture that covers, such as, cultural activities, food, nature, arts.

3)Hands on, that involves tourists to learn interactively, the presence of interpretation facility for tourists, tourists can interact directly with the community members, and handicrafts by local community.

4)Participants are limited to a small group or personal. There is a division of groups for each training hold.

5)The activity is conducted in the teacher's place or workshop/garage, not in a luxurious meeting room. This is to support the authenticity and informal atmosphere. This can be seen from the accessibility to the location/village, location of the performance in an open space, security and cleanliness of the locatoin, the variety of an exhibition and performance. There is an entertainment activity that involves tourists.

6) Allows tourists to explore the creativity of the community so the learning curriculum is not strictly limited (in other words, flexible), that is by dividing groups for each training hold, the type of training given for tourists is varied.

7) Supporting the sustainability tourism by having a market for the capability improvement/traditional skills of a community, and can make use of the existing facilities and infrastructure. Souvenirs for tourists, the awareness to the environment (green industry), by preserving the environment. Able to create creative and various products. There is a public/tourism facilities and infrastructure, and 
the awareness to the environment (green industry).

8)Drawing oneself closer to the local community, including the teacher/instructor and surrounding community members. Various diverse entertainment creativities, a variety of exhibitions for each performance shown, the community involvement in tourism/festival activity, improve the cultural aspect as the traveling motivation to the tourist.

It can be summarized that in a creative summary where the recreational tourism becomes the creative tourism, it is better to be aware that the community involvement is one of significant factors. Hermantoro (2011:117) explains that in the creative tourism, tourists participate more actively towards the attraction delivered by the local community. Creative tourism is a development process of creativity where tourists and local community has a close interactive relation, where they both can participate together in a creative tourism activity.

\section{RESEARCH METHODOLOGY}

This research uses a descriptive research method with the quantitative approach. The quantitative approach in this research is to produce the description, make drawings or sketches systematically, factual and accurately on facts, characteristics and relation between the explored phenomenons. Therefore, by using the quantitative descriptive methode, it is expected that the research can identify the actual condition of creative tourism activities at Cicadas Acoustic Creative Village, Bandung City. The sampling technique used in this research is the probability sampling technique, where the local community of Cicadas has an equal opportunity to be a sample member. The population of Cicadas Acoustic Creative Village, Bandung is the entire RT in RW 04, with 220 Heads of Family, consists of: RT 1 : 46 Heads of Family, RT 2 : 51 Heads of Family, RT 3 : 22 Heads of Family, RT 4 : 55 Heads of Family, and RT 5 : 46 Heads of Family. Based on the formulation of sampling area, we obtained 135 samples of Heads of Familiy.

The data collection technique used is by distributing questionnaire to the Head of Family and interviews with local community figures in Cicadas. The data analysis technique used is descriptive analysis of the questionnaire calculation result and combine it with the interview results of local community figures.

\section{DISCUSSION}

\section{A. The Response from Respondents on Tourists Involvement} in the Self-Development Effort

Based on the result of questionnaire distributed to 135 Heads of Family at Cicadas, it can be summarized that community members are quite agree or still hesitant against the presence of tourists that can develop themselves in Cicadas Area. Therefore in this research, the local community still has not seen the self-development of the tourist visiting Cicadas as the Acoustic Creative Village. This can be seen at the below recapitulation table of respondent's responses on the tourist involvement in the self-development.

TABLE 1

THE RESPONSE FROM RESPONDENTS ON SELF-DEVELOPMENT OF TOURISTS AT CICADAS ACOUSTIC CREATIVE VILLAGE

\begin{tabular}{|c|c|c|}
\hline \multicolumn{3}{|c|}{$(\mathrm{N}=135)$} \\
\hline Indicator & Score & Criteria \\
\hline $\begin{array}{l}\text { The Openness of Community } \\
\text { Towards Tourists }\end{array}$ & 524 & Agree \\
\hline $\begin{array}{l}\text { Creative Tourism Activities that } \\
\text { Involves Tourists }\end{array}$ & 250 & Quite Agree \\
\hline $\begin{array}{l}\text { The Presence of Interpretation } \\
\text { Facility for Tourists }\end{array}$ & 524 & Agree \\
\hline $\begin{array}{l}\text { Tourists Can Interact Directly to } \\
\text { the Local Community }\end{array}$ & 278 & Quite Agree \\
\hline Handicrafts of Local Community & 504 & Agree \\
\hline Indicator & Score & Criteria \\
\hline Group Division & 396 & Quite Agree \\
\hline $\begin{array}{l}\text { Education Activities/Trainings to } \\
\text { Tourists }\end{array}$ & 444 & Quite Agree \\
\hline $\begin{array}{l}\text { Trainings Given to the Tourists } \\
\text { Varied }\end{array}$ & 459 & Quite Agree \\
\hline $\begin{array}{l}\text { Various Entertainment/Arts That } \\
\text { Can Be Learned by the Tourists } \\
\text { During Their Visits in the Village }\end{array}$ & 329 & Quite Agree \\
\hline $\begin{array}{lrl}\text { Community } & \text { Involvement } & \text { In } \\
\text { Festivals/Tourism Activities } & \end{array}$ & 354 & Quite Agree \\
\hline $\begin{array}{l}\text { Improve Cultural Aspect as the } \\
\text { Traveling Motivation to the } \\
\text { Tourists }\end{array}$ & 431 & Quite Agree \\
\hline $\begin{array}{l}\text { Local Community Is Willing To } \\
\text { Help Tourists Going Further In } \\
\text { One of Local Creativities }\end{array}$ & 496 & Agree \\
\hline $\begin{array}{l}\text { Local Community Satisfies When } \\
\text { Tourists Not Only Knowing The } \\
\text { Culture But Can Be Involved In } \\
\text { The Cultural Activities }\end{array}$ & 488 & Agree \\
\hline $\begin{array}{l}\text { The Response from Respondents } \\
\text { that Tourists Can Improve Their } \\
\text { Knowledge on Local Culture of } \\
\text { the Village }\end{array}$ & 492 & Agree \\
\hline $\begin{array}{l}\text { Local Community Allows } \\
\text { Tourists to Involve Directly in } \\
\text { The Making of Handicrafts } \\
\text { Produced }\end{array}$ & 461 & $\begin{array}{l}\text { It is enough } \\
\text { Agree }\end{array}$ \\
\hline $\begin{array}{r}\text { Total Score and } \\
\text { Criteria }\end{array}$ & 6430 & Quite Agree \\
\hline
\end{tabular}

One of the reasons why the community is still hesitant about the tourists involvement on their self-development is the number of tourists visiting Cicadas Creative Village is still lacking. The presence of this Acoustic Creative Village is rarely known by public, particularly people of Bandung City itself. 


\section{B. The Research Result On the Evaluation of Local} Community Towards the Learning on Local Cultural-Based Activities To The Tourists

There are local cultural-based activities that highly influence the creative tourism activity. In this case, the response of the community of Cicadas towards the local culture performed to the visiting tourists is almost entire community agree to be made as a sample. In Cicadas Creative Village, they remain to uphold the typical art and culture of Sunda whenever they hold an event. Following is the recapitulaion result of the community response towards the local culture learning to the tourists.

TABLE 2

RESPONSE OF RESPONDENT ON LEARNING WITH THE FOCUS OF LOCAL CULTURAL-BASED ACTIVITIES TO THE TOURISTS $(\mathrm{N}=135)$

\begin{tabular}{|l|l|l|}
\hline \multicolumn{1}{|c|}{ Indicator } & Score & Criteria \\
\hline $\begin{array}{l}\text { Cicadas Becomes One of Creative } \\
\text { Villages }\end{array}$ & 493 & Agree \\
\hline The acoustic characteristic of Cicadas & 492 & Agree \\
\hline $\begin{array}{l}\text { The Theme of The Village Is In Relation } \\
\text { To The Local Culture }\end{array}$ & 499 & Agree \\
\hline $\begin{array}{l}\text { Sundanese Culture That Remains } \\
\text { Preserved/Strong }\end{array}$ & 458 & Agree \\
\hline $\begin{array}{l}\text { There Is Local Cultural Art Activities } \\
\text { Thetal Score and }\end{array}$ & 407 & Agree \\
\hline Has Special Food & 376 & Quite Agree \\
\hline $\begin{array}{l}\text { There Is Several Attractions In Relations } \\
\text { To The Local Culture }\end{array}$ & 459 & Agree \\
\hline $\begin{array}{l}\text { Accessibility To The Location/Creative } \\
\text { Village Is Easy }\end{array}$ & 399 & Agree \\
\hline $\begin{array}{l}\text { Hold Festival Performance/Tourism } \\
\text { Activities }\end{array}$ & 527 & Agree \\
\hline $\begin{array}{l}\text { Cicadas Creative Village Is Safe For The } \\
\text { Tourist } \\
\text { Performances }\end{array}$ & 489 & Agree \\
\hline $\begin{array}{l}\text { Hastertainment/Art Activities Involving } \\
\text { Pariety Of Exhibitions and }\end{array}$ & 485 & \\
\hline
\end{tabular}

Based on the classification at the above table, it can be interpreted that the response from respondents on such matter is they agree to provide some learnings on local cultural-based activities to the tourists. If it refers to the concept explained by Richard and Raymon (2005), the creative tourism is a learning activity that can be focused on local activities with local skills owned. By having some learning on local cultural-based activities, it can help the creative tourism to be developed more actively in Cicadas.

\section{C.The Research Result On the Evaluation of Local} Community Towards the Enablement of The Use of Local Skills

Hermantoro (2011: 99-107) explains that creative tourism is how to make a recreational tourism be a creative tourism, by prioritizing the role and development of local community, not just become creative people, but capable to be a creativepeneur, being a creative community that also has a deep soul of entrepreneurship. You may see it in the below recapitulation result on the evaluation of the capability indicators to empower skills owned by the community of Cicadas.

TABLE 3

RESPONSES FROM RESPONDENT ON LEARNING OF ENABLING THE USE OF LOCAL SKILLS AT CICADAS ACOUSTIC CREATIVE VILLAGE

\begin{tabular}{|c|c|c|}
\hline \multicolumn{3}{|c|}{$(\mathrm{N}=135)$} \\
\hline Indicator & Score & Criteria \\
\hline $\begin{array}{l}\text { Various Types of Souvenirs At } \\
\text { Cicadas Creative Village }\end{array}$ & 343 & Disagree \\
\hline $\begin{array}{l}\text { The Creative Products Produced } \\
\text { Are Environmentally Friendly }\end{array}$ & 479 & $\begin{array}{l}\text { Quite } \\
\text { Agree }\end{array}$ \\
\hline $\begin{array}{l}\text { There Are Groups (Partnership) of } \\
\text { Craftsmen Participating In The } \\
\text { Creativity }\end{array}$ & 392 & $\begin{array}{l}\text { Quite } \\
\text { Agree }\end{array}$ \\
\hline $\begin{array}{l}\text { There Is A Variety of } \\
\text { Handicrafts/Products }\end{array}$ & 414 & $\begin{array}{l}\text { Quite } \\
\text { Agree }\end{array}$ \\
\hline $\begin{array}{l}\text { There Is A Unique/Distinct } \\
\text { Direction Sign For Tourists }\end{array}$ & 378 & Disagree \\
\hline $\begin{array}{l}\text { There Is A Parking Spot For } \\
\text { Tourists }\end{array}$ & 362 & Disagree \\
\hline $\begin{array}{l}\text { There Is A Special Area For } \\
\text { Tourists To Make Creative } \\
\text { Products }\end{array}$ & 363 & Disagree \\
\hline $\begin{array}{r}\text { Total Score and } \\
\text { Criteria }\end{array}$ & 2731 & Disagree \\
\hline
\end{tabular}

Everything has its process, and this is what happen in Cicadas. By becoming one of creative villages in Bandung City forces the local community of Cicadas to be more active and creative, and in this case is to maintain the existence of nickname assigned by the local government of Bandung City, that is the Acoustic Creative Village.

The lack of attention given by the local government of Bandung City causes the local community of Cicadas becomes less enthusiast to empower their creative capability further, particularly their creativity products.

The creative tourism has the potential to be developed in Cicadas, but the situation can be manifested in relation to the presence of the stakeholders. Role of the government is very significant in developing the tourism in Cicadas. Fund is one of obstacles complained by the local community of Cicadas. The lack of attention given by the government has made the local community of Cicadas becomes less enthusiast to produce, even develop their creativity potential owned. 
The effort to develop creative tourism in Cicadas as the Acoustic Creative Village is to recognize the desire of local community. This must be recognized by the local government of Bandung City or for other party that has the interest in tourism sector, in order to know the weakness or advantages of a tourism product or service that has been held all this time.

It is expected that stakeholders or parties that have the role in the development of Cicadas are able to improve the existing weaknesses according to their expectation, thus Cicadas can become an alternative tourism area in Bandung City in the future, which can bring tourists. Therefore it is expected that it can improve the economy level of the community in Cicadas area.

\section{V.CLOSURE}

Cicadas is very lacking, therefore the creative tourism activities still cannot run well actively. However, the community is very open and supportive to tourists in the selfdevelopment through their involvement and participation in tourism and cultural activities owned, as well as in daily activities done by the local community. Majority of the local community of Cicadas agrees to have trainings and learnings given to tourists, so the visiting tourists not just visiting but can enrich their knowledge on culture and creativity of local community of Cicadas, Bandung. With no availability of special place or room for training makes it difficult for the community of creative village to set a special locatoin and training schedule. The community still does not understand how to be a local community that is capable to be independent, active with all creativity owned in developing the Acoustic Creative Village as one of creative villages in Bandung City, which later is expected to be the tourist destination and one of choices of alternative tourism in Bandung City.

Role of the government, in this case is the local government of Bandung City, should be able to provide more trainings and serious supervisions to Creative Village, which later become one of alternative tourism destinations in Bandung City. This is carried out by several ways, namely the government provides many rewards and appreciation to the local community and creative works produced, mapping the existence of creative villages in Bandung City based on its own theme that is already assigned by the Local Government of Bandung City, and to build more open public spaces or a special place for the local community as the place to sharpen their creativity. In addition to that, the government must be able to generate policies that can create a condusive business climate for the creative industry so the community can have high entrepreneurship soul.

The community can establish an organization to manage Cicadas that aims to improve the efforts made in order to increase the promotional intensity so many more people know about the existence of Cicadas. Furthermore, youth of Cicadas can optimize the function of social media as the media to distribute informatoin on culture, arts and creativity of Cicadas Acoustic Creative Village to a wider community. Informatoin can be in the form of the history of Cicadas that becomes a creative village of Bandung city, the environmental circumstances, the format of creativity owned, the local culture of the community, even social issues and values contained in a building, so it is important to preserve its presence. Furthermore, the community also participates in social actions and working together with communities from other creative villages, even with communities in other sectors to optimize the function of the community as a place for creativity and the bridge between community, private sector and the Government.

\section{REFERENCES}

[1] Hermantoro, Henky. 2011. Creative-Based Tourism Dari Wisata Rekreatif Menjadi Wisata Kreatif. Aditri.Depok, Jabar

[2] Klingner, Kristen. 2006. Urban Tourism in Hamburg and the World Cup, GRIN Verlag. Germany.

[3] Priyatmono. 2011. Profil Kampoeng Batik Laweyan Tahun 2004 Tahun 2011. FPKBL. Surakarta.

[4] Richard, Greg and Wilson, Julie. 2008.Tourism, Creativity, and Development, Routledge, Oxon.

[5] Richard, G. and Raymond, C. 2000. Creative Tourism. ATLAS News (23), 16-20.

[6] Safira. 2012. Kampung Kreatif Sebuah Solusi Spasial Pemenuhan Kebutuhan Manusia. Thesis of Universitas Indonesia. 